\title{
КОНЦЕПТУАЛЬНА МОДЕЛЬ КОРЕКЦІЇ НЕГАТИВНИХ ПСИХІЧНИХ СТАНІВ ТА ПСИХОСОМАТИЧНИХ РОЗЛАДІВ У ДІТЕЙ ДОШКІЛЬНОГО ВІКУ ЗАСОБАМИ ТІЛЕСНО-ОРІЄНТОВАНОЇ ТЕРАПІЇ
}

УдК: 159.922 .6

\section{Ревуцька Ірина Вікторівна}

\begin{abstract}
Стажист-дослідник кафедри управління Державного вищого навчального закладу «Університет менеджменту освіти», Національна академія педагогічних наук України, Київ (Украӥна)
\end{abstract}

\begin{abstract}
Анотація. Стаття присвячена негативним психічним станам і психосоматичним розладам дітей дошкільного віку та засобам їх корекції. Проаналізовані деякі публікації відносно емочійних порушень та факторів їх виникнення у дошкільників.

У статті розглянута парадигма тілесно-орієнтованої терапії відомих учених світу, з урахуванням якої були розроблені корекційні заходи подолання даної проблеми. Представлено концептуальну модель корекиії негативних психічних станів і психосоматичних розладів дітей дошкільного віку, ї̈ структурні компоненти та психотехнологія реалізації.

Розглянуто корекційну програму та види контактів подолання негативних психічних станів і психосоматичних розладів дітей дошкільного віку. Розглянуті програмні комплекси за напрямом «Активізація» та «Розслаблення», а також техніки і прийоми їх виконання.
\end{abstract}

Ключові слова: психосоматика, негативні психічні стани, тілесно-орієнтована терапія, дошкільники, контакт, картографія тіла.

Постановка проблеми. На підставі того, що негативні психічні стани безумовно впливають на соматичні прояви та проблеми дитини, і того, що існують різні методи корекції негативних психічних станів, які допомагають змінити соматичний фон проблем, зазначимо, що роль їх впливу на регуляцію негативних психічних станів через роботу з тілом практично мало вивчена у віковій та педагогічній психології. Тому, перспективними пред- ставляється використання тілесноорієнтованої терапії, не тільки як засобу діагностики, а як і способу корекції негативних психічних станів та психосоматичних розладів у дітей дошкільного віку.

Аналіз останніх досліджень і публікацій. Проблема психосоматичних розладів у дітей дошкільного віку відноситься до фундаментальних проблем вікової та педагогічної психології, основні положення яких розкриті в 
роботах Ф. М. Александера, В. Ю. Баскакова, Д. Боаделли, О. Лоуена, Л. Марчел, В. Райха, М. Фельденкрайза та ін. Так, Ф. М. Александер [1] заснував техніку навчання інтегрованим рухам, В. Ю. Баскаков [2] розробив метод «Танатотерапія», що дозволяє використовувати глибинні стани тілесних відчуттів для переоцінки багатьох життєвих проблем. Д. Боаделла [3] представив інший метод соматичної терапії - «Біосинтез», який спонукає людину до особистісного зростання і цілісного розвитку, що дозволяє зцілити і зв'язати воєдино почуття, розум і тілесні відчуття.

Іншій підхід у даному напрямі представив О. Лоуен [7]. Він є засновником методу «Біоенергетика», сутність якого у знятті напруги у людини за допомогою фізичних вправ і певних поз та «заземлення» (злиття з природою, тобто, укорінення) в рамках фізичного, емоційного та інтелектуального аспектах. Засновником бодинамічного аналізу - методу уявлення психології вікового розвитку, анатомії та вікової фізіології нервово-м'язової системи - стала Л. Марчел [8], яка описала динаміку фізичного розвитку дитини, іiі паралелізм 3 особистісним розвитком. Усвідомленням і розвитком тілесної енергії займався М. Фельденкрайз [12], який розробив метод «Соматичного навчання».

Особливу увагу привертає В. Райх [9], засновник тілесної терапії, який першим довів, що м'язовий і психологічний панцир являють собою єдиний процес, саме він створив техніки зменшення хронічної напруги в кожній групі м'язів за допомогою фізичних дій, завдяки яким вивільняються заблоковані емоції і почуття.

Ряд дослідників дитячого віку Л. І. Божович, А. Валлон, Л. С. Виготський, Д. Б. Ельконін, А. В. Запорожець, Р. Заззо, В. В. Зеньковський, Л. О. Калмикова, Т. О. Піроженко, А. Н. Леонтьєв, Н. С. Лейтес В. С. Мухіна, B. Bain, M. Haworth та ін., указують на «неповторність, особову значимість» цього періоду для всього наступного розвитку людини. Вони розглядають дошкільне дитинство, як особливо відповідальний період, коли закладаються основні особистісні механізми, виникає перша модель світу - система уявлень про навколишню дійсність, про свої можливості і стосунки 3 оточуючими людьми. О. М. Леонтьєв зазначав, що дошкільний вік, це період первісного, фактичного складу особистості.

Багато авторів, таких як Л. А. Абрамян, Р. Н. Досаєва, А. В. Запорожець, А. І. Захаров, В. Котирло, А. Д. Кошелева, Я. 3. Неверович, Р. В. Овчарова, Т. О. Смолева, Т. А. Хвиюзова, К. Хорні та ін., розглядають психічні стани у нормі та з її порушенням. Підкреслимо, що А.Д. Кошелєва, А. В. Запорожець, Я. 3. Неверович, наголошують, що діти у дошкільному віці не завжди можуть усвідомлювати, які стан вони відчувають, і тим більше причини їх виникнення. Враховуючи цей факт, О. Б. Ігумнова стверж- 
дує, що негативні психічні стани необхідно розглядати у комплексі [5].

За дослідженнями таких науковців як Л. А. Абрамян, А. І. Захаров, А. Д.Кошелева, Т. О. Смолева, Р. В. Овчарова, Т. А. Хвиюзова та ін., емоційні порушення виникають саме під впливом несприятливих факторів соціального середовища, таких як: сімейна дезадаптація (емоційно неблагополучна обстановка в родині, конфліктні відносини між близькими родичами, відсутність узгодженості між батьками, ситуація розлучення батьків), соціальна дезадаптація (міграція), психосоматичні розлади (перенесені хвороби, госпіталізація, часті ГРВІ, алергія).

Також, на виникнення психосоматичних розладів та світовідчуття дитини впливає соціально-економічне положення сім’ї. За дослідженнями Ц. Дамянова, M. E. DesseillesLawalree, A. Gortmaker, B. Gustin, R. L. Huenemann, R. H. Maaser, Q. Monti, H. Stolley, A. Stunkard у дітей із сімей з низьким соціально-економічним рівнем частіше, ніж у сім'ях 3 високим, виникає ожиріння. Ці дослідження були проведені у США, Великобританії, Болгарії, Франції, Італії: ожиріння розповсюджене у дитячому віці, а саме у дошкільному віці поширюютєся між 2-ма і 6-тю роками [6]. За дослідженнями $R$. Schwartz, у США, Скандинавії та ФРГ виявлено, що психосоціальні фактори приймають участь у походженні сахарного діабету і у дошкільному віці, до 5-ти років складає 1:1430 дітей [6].
Мета дослідження. Метою даної статті $\epsilon$ теоретичний аналіз концептуальної моделі корекції негативних психічних станів і психосоматичних розладів дітей дошкільного віку засобами тілесно-орієнтованої терапії.

Виклад основного матеріалу і результатів дослідження. Аналіз існуючих напрямів тілесно-орієнтованої терапії дозволив виокремити основні корекційні методичні прийоми, а також розкрити їх значення, роль і ступінь ефективності в роботі з дітьми дошкільного віку. 3 нашої точки зору, найбільш перспективними й ефективнішими для роботи 3 негативними психічними станами та психосоматичними розладами є такі техніки як: дихальні, релаксаційно-сенситивні, масажні, хептичні (невербальне спілкування - жести, пози, міміка, дотик), альтернативні (робота 3 тілом заземлення).

Вивчення літературних джерел з даної проблеми показав відсутність відповідних методик діагностики. Тому для дослідження психосоматичних розладів у дітей дошкільного віку, нами була розроблена анкета для батьків «Діагностична бесіда з батьками про психосоматичні проблеми дитини», за допомогою якої були встановлені категорії проблем та розроблена корекціна програма тілесно-орієнтованої терапії, це розлади шлунково-кишкового тракmу $i$ травної системи (порушення стільця (запори, пронос), порушення апетиту (зниження або підвищення), «роздратований шлунок», збочення апетиту (вживання нехар- 
чових речовин), аерофагія, здуття живота, нудота, блювання, болі в животі, метеоризм, відмова від жування, непереносимість окремих видів їжі, анорексія та булемія; проблеми ресnіраторної системи (задишка, нав'язливий кашель, утруднення вдиху, бронхіальна астма, псевдо-астматичні напади, астматичні напади); алгії синдромного характеру та їх поєднання (головний біль (цефалгія), біль у м'язах (міальгія), суглобах (артралгія), сечовому міхурі та інших органах [10].

Послідовно охарактеризуємо та обгрунтуємо створення тілесно-орієнтованої концептуальної моделі корекції негативних психічних станів і психосоматичних розладів дітей дошкільного віку та уточнимо понятійний апарат.

Модель (фр. modèle, від латів. modulus «міра, аналог, зразок») - це представлення реального пристрою і процесів, явищ, що протікають в ньому, для вивчення наявних властивостей і закономірностей. У контексті нашого дослідження, модель - це структура, яка $є$ системним зображенням діагностики i корекції негативних психічних станів і психосоматичних проблем дітей дошкільного віку 3 урахуванням взаємодії видів контакту і напряму регуляції, результат впливу яких представлено рівнями реагування на способи тілесноорієнтованої терапії у рамках динаміки змін негативних психічних станів і психосоматичних проявів.

Тілесно-орієнтована терапія - це група методів психотерапіі, орієнтованих на вивчення тіла, розуміння процесів, що протікають в ньому, усвідомлення тілесних відчуттів, переживань, дослідження потреб, бажань i почуттів, які виражаються в різних тілесних проявах з наступною корекцією їх розладів.

В структурі запропонованої концептуальної моделі корекції негативних психічних станів і психосоматичних розладів дітей дошкільного віку виокремлено три взаємопов'язані блоки: тілесна діагностика негативних психічних станів 3 використанням «Картографії тіла дитини» для виявлення і корекції психосоматичних проблем у дошкільників, корекційна програма по подоланню негативних психічних станів та психосоматичних розладів у дітей дошкільного віку засобами тілесно-орієнтованої терапії та результативно - динамічний структурний компонент для визначення динаміки змін залежно від корекційних заходів (див. Рис. 1).

Кожен із структурних компонентів моделі має свою мету, завдання, низку методів і прийомів, особливості їх використання.

Так, метою першого emany (діагностичного) є отримання інформації, необхідної для цілеспрямованого підбору тілесно-орієнтованих методів корекції. Даний етап включає в себе завдання:

- по-перше, вивчення негативних психічних станів, тілесних проявів або психосоматичних розладів та індивідуальнопсихологічних особливостей дітей дошкільно- 
го віку;

- по-друге, за даними експерименталь- ного дослідження з урахуванням психологічного профілю дошкільників, збігу критеріїв

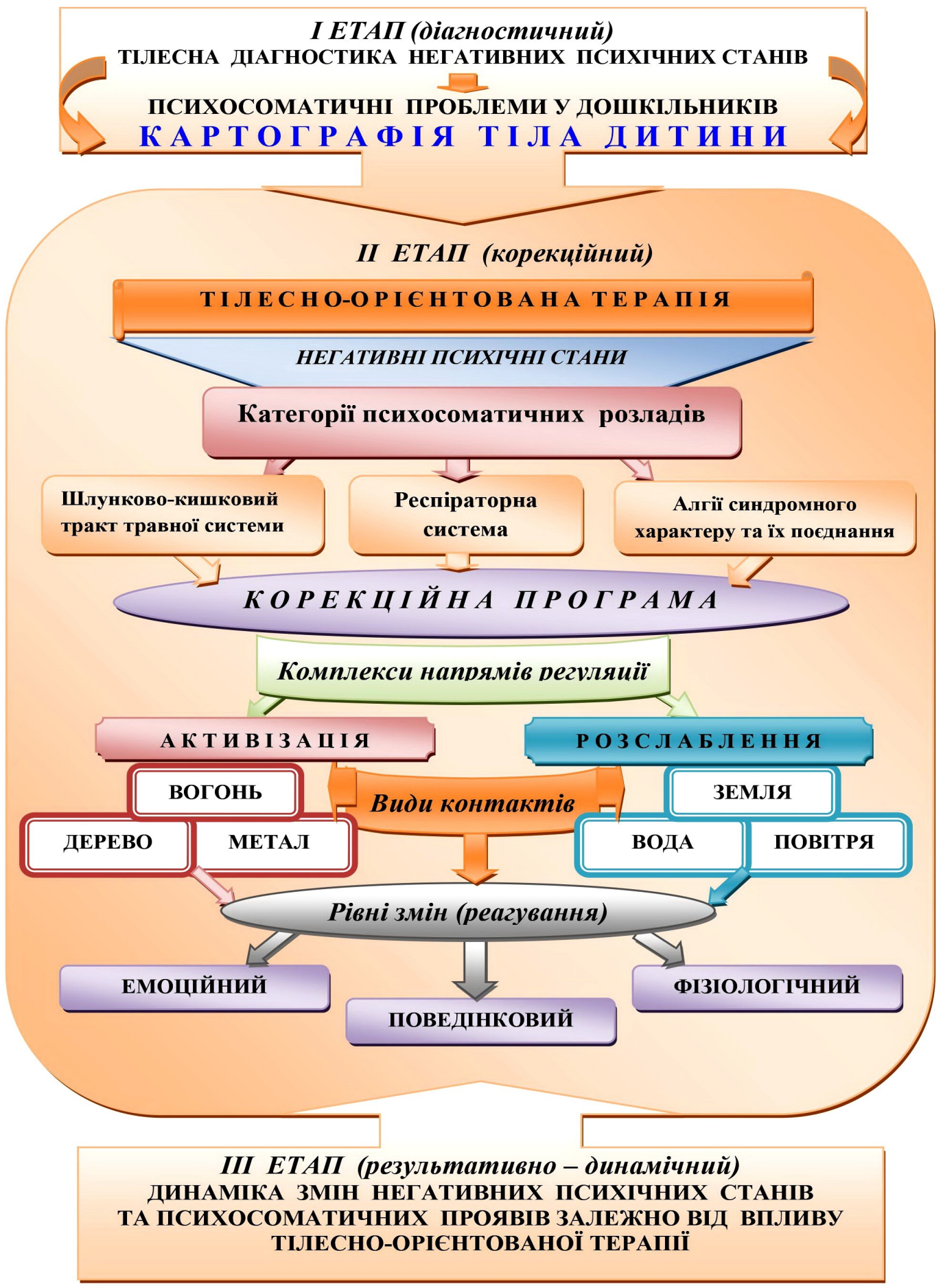

Рис. 1. Концептуальна модель корекції негативних психічних станів та психосоматичних розладів у дітей дошкільного віку засобами тілесно-оріснтованої терапії 
впливу розробити програмні комплекси засобами тілесно-орієнтованої терапії.

Метою другого еmany (корекційного) $\epsilon$ регуляція негативних психічних станів та психосоматичних розладів засобами тілесноорієнтованої терапії. Завданням даного етапу $€$ :

- nо-перше, виокремити категорії психосоматичних розладів (перелічені вище);

- по-друге, розробити корекційну програму тілесно-орієнтованої терапії для подолання психосоматичних розладів та негативних психічних станів дошкільнят;

- no-третє створити комплекси напрямів регуляції «Активізація»/ «Розслаблення»;

$\Rightarrow \quad$ по-четверте, підібрати види контакту в рамках зазначених напрямів регуляції з метою досягнення оптимального стану і психосоматичного комфорту дитини дошкільного віку.

- no-n'яте, прослідкувати за змінами, які відбулися після запропонованих корекційних заходів на емоційному, поведінковому та фізіологічному рівнях реагування.

Програмні комплекси напрямів регуляції складаються з наступних видів контакту:

вогонь, дерево, метал - напрями активаціï (для виведення напруги в тілі, запуску здорового опору, спрямовані струсити та змінити активність дитини);

земля, вода, повітря - напрями розслаблення (розслаблення, встановлення відчуття підтримки).

Дані комплекси контактів спрямовані на зняття тілесних і психологічних затисків, фізичне і душевне розкріпачення і набуття почуття гармонії з навколишнім світом.

Зробити висновок про ефективність корекції за допомогою тілесно-орієнтованої терапії можна за змінами наступних рівнів: емоційного, поведінкового, фізіологічного, що і заплановано у п'ятому завданні.

Метою третього

emany (результативно-динамічного) є вивчення динаміки змін негативних психічних станів та психосоматичних проявів за допомогою тілесноорієнтованої терапії, які відбулися під впливом корекційних заходів.

Для перевірки ефективності корекції негативних психічних станів та психосоматичних розладів у дітей дошкільного віку також було використано ряд методичного інструментарію, який підтвердив ефективність запропонованої концептуальної моделі, в основі якої лежить тілесно-орієнтована терапія.

Отже, ми розглянули структурні компоненти концептуальної моделі, які включають комплекс організаційних психологічних заходів, операцій і прийомів, спрямованих на досягнення поставленої мети [4, с. 353]. У нашому дослідженні такими є: категорії психосоматичних розладів, зміст програмних комплексів, їх складові частини, специфіка підбору матеріалу до програмних комплексів, напрями регуляції, види контактів, критерії 
опису використаних технік, особливості організації виконання сеансів тілесноорієнтованої терапії, гігієнічні вимоги до іiі застосування, тобто представлено створення i впровадження тілесно-орієнтованої психотехнології корекційного етапу - концептуальної моделі - у досягненні оптимального стану і психосоматичного комфорту дитини дошкільного віку.

Тепер стисло охарактеризуємо корекційну програму подолання негативних психічних станів і психосоматичних розладів дітей дошкільного віку, одному з головних компонентів концептуальної моделі, в якій виокремлено три взаємоповязані блоки: тілесна діагностика негативних психічних станів з використанням «Картографії тіла дитини» для виявлення і корекції психосоматичних проблем у дошкільників, корекиійна програма по подоланню негативних психічних станів та психосоматичних розладів у дітей дошкільного віку засобами тілесно-орієнтованої терапії та результативно - динамічний структурний компонент для визначення динаміки змін залежно від корекційних заходів.

Мета корекційної програми добитися оптимального стану і психосоматичного комфорту дитини дошкільного віку.

При розробці корекційної програми тілесно-оріснтованої терапї враховувались: вік респондентів, категорія психосоматичних розладів, мотиваційна готовність дитини до роботи, психічний та фізичний стан дитини, а також об'єктивні і суб'єктивні критерії напрямів регуляції, що забезпечать максимальну ефективністю впливу.

Об'єктивні: досягнення катарсису (характеризується миттєвою зміною картини світу, врівноваженістю, гармонійним станом); феномен інерції (нездатність без сприяння зовнішніх сил змінити наявний стан);

$$
\text { Суб'єктивні: експресивність }
$$

(характеризується інтенсивністю: емоційні враження, фізіологічні зміни); динамічність (характеризується впливом на поведінку і діяльність: стимулюючу/гальмуючий в залежності від типу запропонованої програми «Активізація»/«Розслаблення»).

Для дослідження ефективності тілесноорієнтованої терапії на емоційному, поведінковому та фізіологічному рівнях змін, тобто рівнях реагування на види контактів в рамках напряму «Активізація»/«Розслаблення», для виявлення динаміки змін негативних психічних станів та психосоматичних розладів у дітей дошкільного віку засобами тілесноорієнтованої терапії проводилося по п’ять сеансів за кожним комплексом регуляції («Активізація»/〈Розслаблення») з використанням трьох видів контакту: «Вогонь», «Дерево», «Метал» для активізації; «Земля», «Вода», «Повітря» для розслаблення. Кожен сеанс має загальну тривалість часу - 40 хвилин, з них: вступному етапу відводиться 6 хв., основному - 25 хв., заключному - 9 хв. Батькам дається домашнє завдання з установкою 
на його виконання вдома на протязі 60 хвилин.

Тепер більш суттєво подамо інформацію дотичне використання контакту. Контакт, це вплив на дитину в ході тілесноорієнтованої терапії, який може бути словом, поглядом, дотиком. Інструмент, через який буде проведено контакт, є дотик - матеріальне втілення контакту. Типи дотиків класифікуються відповідно до китайської системи елементів, які діляться за шістьма видами: земля, вода, повітря, вогонь, дерево, метал, та спрямовані на активізацію або розслаблення.

Опишемо комплекс напряму регуляції «Активізація". Процес активізації це накопичення енергії, що під час терапії проявляється через психічний стан дитини, емоції, які своєчасно не були реалізовані (сміх, плач, кашель, суха блювота), а на фізіологічному рівні - почервоніння лиця, зони шиї та грудей, можливі висипання, у щелепному відділі голови посилюється напруга (виникає бажання вкусити), що виглядає як оскал. Даний комплекс складається з таких видів контакту, як дерево, метал, вогонь. Послідовно опишемо всі типи контактів активації.

Так, контакт «Дерево» допомагає у корекції таких негативних психічних станів, як гнів та жорстокість. На рівні тіла частіше застосовується в зоні печінки. Прийом виконання - видавлювання, підтримка (сильні, щільні, дотики, що тиснуть на тіло ліктем, пальцем, рукою). Основна функція цього контакту, $\epsilon$ посилення енергетики зони дотику, активізувати iіi, в деякому роді спровокувати опір [1; 11; 13, с. 190-194].

Наступний контакт «Метал» має схожу техніку виконання, але більш жорстку та застосовується в роботі зі станами печалі, депресії, образи. На рівні тіла частіше виконується в зоні легенів і товстого кишечника [1; $11 ; 13$, с. 189].

Описуючи контакт «Вогонь» зазначимо, що він застосовується в роботі зі станами нудьга, злість, жорсткість, неповага. На рівні тіла виконується в зоні грудей, кінцівок, голови, плечей. Прийоми виконання - віджимання, осциляція (покачування), щипання [1; 11, c. $79 ; 13$, с. 195-197].

Другим комплексом корекційної програми тілесно-орієнтованої терапії в рамках напряму «Регуляція», є розслаблення, тобто, наповнення тіла енергією. Даний комплекс починається тілесним трансом, який змінюється релаксацією. Так, тілесний транс - це процес, коли енергія в тілі дитини стягується до центру, кінцівки стають холодними, дихання стає глибоким, загострюються риси обличчя, на погляд, тіло ніби кам'яніє, а на дотик стає розслабленим, активується свідомість, розумові процеси починають вирішуватися в тілі саме під час глибокого відпочинку, релаксації. Процес релаксації супроводжується розігрівом тіла, яке збільшується в розмірі, ніби тіло розтікається по сторонах, а у цей час емоції відсутні. Максимальне розслаблення 
наступає упродовж двох годин після роботи. Даний комплекс складається 3 таких видів контакту, як земля, вода, повітря.

Більш детально зупинімось на даних типах контакту. Так, контакт «Земля» допомагає у корекції таких негативних станів, як заздрість, скорбота, меланхолія, дратівливість. На рівні тіла, це зона селезінки, спина, живіт, кінцівки, голова. Прийомами застосування $€$ вертикальна настройка дихання (дотик до тіла та рух руки разом з тілом в резонансі з диханням), гомеопатична ротація (повільне, ніби мікрорухи, відведення кінцівки в бік), театр дотиків (поступові, повільні, глибокі дотики, ніби рука входить в тіло як в масло). Контакти типу «земля»не пов'язані з диханням, в роботі 3 тілом вони використовуються в першу чергу тоді, коли необхідно дати дитині відчути якусь реальність навколишнього світу, нагадати їй, що вона жива, знаходиться на землі і взагалі існує тут і тепер $[1 ; 11$, с. $77 ; 13$, с. 158-168].

Ще одним контактом $є$ «Вода», даний контакт працює зі станами страх, параноя, на рівні нирок, сечового міхура, голови, тіла в цілому. Прийомами виконання $\epsilon$ гребінь (стягування енергії навколо тіла не торкаючись його), прогладжування, стягування (ніби струшування води 3 кінцівок). Це рухливі дотики, під час яких рука терапевта переміщається по тілу дитини. Такі дотики в житті зустрічаються найчастіше у відносинах батьків 3 дітьми $[1 ; 11$, с. 79; 13. с. 168-177].
Останнім контактом $є$ «Повітря», що застосовується в роботі зі станами напруження, депресії. На рівні тіла, це легені. Тиск на зону дотику змінюється в залежності від фази подиху, наприклад, контакт стає більш щільним, трохи тисне на протязі всього вдиху, а під час видиху тиск зменшується. Можливий і зворотний варіант, коли тиск виникає на вдиху, а на видиху зникає. Прийомами використання $\epsilon$ діагональна настройка дихання (повільне витягування кінцівки на вдиху i, повільне відпускання на видиху), гомеопатичне витягування (дуже повільне витягування кінцівок упродовж кількох хвилин), решітка виконується в зоні шиї, руки складаються решіткою під шиєю та дуже повільно, під тяжінням шиї пальці розпускаються самі $[1 ; 11$, с. 78 ; 13, c. 177-188].

По виконанню необхідного типу контакту робота переходить у заключний eman, на якому виконується заземлення, а саме - накладання рук на стопи дитини та повільне їх відведення.

Висновок. Таким чином, спираючись на передовий досвід світових учених, проведений теоретичний аналіз проблеми психосоматичних розладів у дітей дошкільного віку у вітчизняній і зарубіжній психології, нами представлена концептуальна модель корекції негативних психічних станів та психосоматичних проблем, сформовані принципи, за якими було розроблено корекційну програму тілесно-орієнтованої терапії, що заснована на ком- 
плексному використанні різних типів контактів за напрямами регуляції «Активізація» та «Розслаблення». Подано послідовне описання технік та прийомів виконання тілесноорієнтованої терапії в роботі 3 дітьми дошкільного віку, сформовано вимоги і рекомендації до техніки їх виконання, подано конкретні блок-схеми, доведення алгоритму яких спонукає до практичної діяльності особистості (рухи тіла, жести, м'язові затиски, пози, дихання), i, як засоби зворотного зв'язку, призводять до оптимізації психічних станів, і психосоматичного комфорту дитини дошкільного віку.

\section{Перспективами подальшого до-}

слідження $\epsilon$ впровадження у дитячі садки запропонованої корекційної програми подолання негативних психічних станів та психосоматичних розладів у дітей дошкільного віку методом тілесно-орієнтованої терапії.

\section{Перелік використаних джерел:}

1. Александер Ф. Психосоматическая медицина. Принципы и практическое применение / Ф. Александер; [пер. с англ. С.Могилевского]. - М.: ЭКСМО-Пресс, 2002. - 352 c.

2. Баскаков B. Ю. Хрестоматия по телесноориентированной психотерапии и психотехнике. Свободное тело / В. Ю. Баскаков. - М.: Институт Общегуманитарных Исследований, 2004. - 224 с.

3. Боаделла Д. Биосинтез. Потоки жизни; [пер. с англ. / Под ред. $\quad$ В.Б. Березкиной-Орловой]. - М.: Центр психологического консультирования и телесной психотерапии, 2016. - 448 с.
4. Волженцева И. В. Методологические и теоретикоэмпирические аспекты полифункциональной регуляции психических состояний личности эмоциогенными способами : монография / И.В.Волженцева; Макееский экономико-гуманитарный институт. - Макеевка: МЭГИ, Донецк : Донбасс, 2012. - 536 с.

5. Ігумнова О. Б. Генеза негативних психічних станів студентів та їх психокорекція: дис. на здоб. наук. ступ. канд. психол. наук: спец. 19.00.07 / О.Б.Ігумнова; Хмельницький національний університет. - Хмельницький, 2014. - 275 c.

6. Исаев Д. Н. Эмоциональный стресс, психосоматические и соматические расстройства у детей / Д.Н. Исаев. - СПб.: Речь, 2005. - 400 с.

7. Лоуэн А. Психология тела: биоэнергетический анализ тела / А.Лоуэн; [пер, с англ. С.Коледа] - М.: Институт Общегума-нитарных Исследований, 2000. - 256 с.

8. Марчер Л. Травма рождения: метод ее разрешения [Електронный ресурс] / Л.Марчер, П.Бернард, Л.Олларс, П.Бернард // Психологическая библиотека 2003. - 21 с. - Режим доступа к книге: http:// bookap.info/psyanaliz/ travma_rozhdeniya_metod_ee_razresheniya/

9. Райх В. Анализ характера / В. Райх. - М.: ЭксмоПресс, Апрель-Пресс, 2000. — 528 с.

10. Ревуцька I. В. Концептуальний підхід до діагностування психосоматичних проявів у дітей дошкільного віку / І.В. Ревуцька // Науковий журнал Огляд № 2(45), 2018. C. 200-210.

11. Тимошенко $Г$. В. Работа с телом в психотерапии: Практическое руководство / Г.В. Тимошенко, Е.А. Леоненко - М: Психотерапия, 2006. — 480 с.

12. Фельденкрайз M. Сознавание через движение: двенадцать практических уроков / М. Фельденкрайз; [пер. с англ. М. Папуш] - М.: Институт Общегуманитарных Исследований, 2001. - 160 с.

13. Шубина E. В. Основы телесной терапии. Иллюстрированное руководство для профессионалов / Е.В. Шубина - СПб.: Наука и Техника, 2007. - 240 с. 


\section{References (Transliteration):}

1. Aleksander F. Psihosomaticheskaya meditsina. Printsipyi i prakticheskoe primenenie. / F. Aleksander; [per. s angl. S.Mogilevskogo]. — M.: EKSMO-Press, 2002. — 352 s.

2. Baskakov V. Yu. Hrestomatiya po telesnoorientirovannoy psihoterapii i psihotehnike. Svobodnoe telo / V. Yu. Baskakov. - M.: Institut Obschegumanitarnyih Issledovaniy, 2004. - 224 s.

3. Boadella D. Biosintez. Potoki zhizni; [per. s angl. / Pod red. V.B. Berezkinoy-Orlovoy]. — M.: Tsentr psihologicheskogo konsultirovaniya i telesnoy psihoterapii, 2016. $-448 \mathrm{~s}$.

4. Volzhentseva I. $\quad$. Metodologicheskie i teoretikoempiricheskie aspektyi polifunktsionalnoy regulyatsii psihicheskih sostoyaniy lichnosti emotsiogennyimi sposobami : monografiya / I.V.Volzhentseva; Makeeskiy ekonomiko-gumanitarnyiy institut. - Makeevka: MEGI, Donetsk : Donbass, 2012. - 536 s.

5. Igumnova $O$. B. Geneza negativnih psihIchnih stanIv studentIv ta Yih psihokorektsIya: dis. na zdob. nauk. stup. kand. psihol. nauk: spets. 19.00.07 / O.B.Igumnova; Hmelnitskiy natsIonalniy unIversitet. - Hmelnitskiy, 2014. $-275 \mathrm{~s}$.

6. Isaev D. N. Emotsionalnyiy stress, psihosomaticheskie i somaticheskie rasstroystva u detey / D.N. Isaev. - SPb.: Rech, 2005. - $400 \mathrm{~s}$.

7. Louen A. Psihologiya tela: bioenergeticheskiy analiz tela / A.Louen; [per, s angl. S.Koleda] — M.: Institut Obscheguma $\neg$ nitarnyih Issledovaniy, 2000. - $256 \mathrm{~s}$.

8. Marcher L. Travma rozhdeniya: metod ee razresheniya [Elektronnyiy resurs] / L.Marcher, P.Bernard, L.Ollars, P.Bernard // Psihologicheskaya biblioteka - 2003. - $21 \mathrm{~s}$.

- Rezhim dostupa k knige: http://bookap.info/psyanaliz/ travma_rozhdeniya_metod_ee_razresheniya/

9. Rayh V. Analiz haraktera / V. Rayh. - M.: Eksmo-Press, Aprel-Press, 2000. — $528 \mathrm{~s}$.

10. Revutska I. $V$. Kontseptualniy pIdhId do dIagnostuvannya psihosomatichnih proyavIv u dItey doshkIlnogo vIku / I.V. Revutska // Naukoviy zhurnal Oglyad \# 2(45), 2018. S.
200-210.

11. Timoshenko G. V. Rabota s telom v psihoterapii: Prakticheskoe rukovodstvo / G.V. Timoshenko, E.A. Leonenko - M: Psihoterapiya, 2006. — 480 s.

12. Feldenkrayz M. Soznavanie cherez dvizhenie: dvenadtsat prakticheskih urokov / M. Feldenkrayz; [per. s angl. M. Papush] - M.: Institut Obschegumanitarnyih Issledovaniy, 2001. - $160 \mathrm{~s}$.

13. Shubina E. $V$. Osnovyi telesnoy terapii. Illyustrirovannoe rukovodstvo dlya professionalov / E.V. Shubina SPb.: Nauka i Tehnika, 2007. - 240 s.

\section{Revutskaya Irina}

Internship researcher of the Department of Management, specialty "Psychology» at State Higher Educational Institution "University of Management of Education" of The National Academy of Educational Sciences of Ukraine, Kyiv (Ukraine)

\section{THE CONCEPTUAL MODEL OF CORRECTION OF NEGATIVE MENTAL STATES AND PSYCHOSOMATIC DISORDERS IN \\ PRESCHOOL CHILDREN BY MEANS OF BODY-ORIENTED THERAPY}

\section{ABSTRACT}

The article is devoted to negative mental states and psychosomatic disorders of preschool age children and means of their correction. The article examines the research of Russian and world scientists on the uniqueness of preschool age, its influence all subsequent development of man. Particular attention is given to mental states, at this age, which cause psychosomatic problems. The paradigm of bodily-oriented therapy of well-known scientists of the world is considered, according to which corrective measures to overcome this problem were developed. The 
techniques of work with negative mental states and psychosomatic disorders of preschool children are considered. The conceptual model of correction of negative mental states and psychosomatic disorders of preschool children is described, which includes the following structural components: physical diagnostics of negative mental states using "Child Mapping" for the detection and correction of psychosomatic problems in preschool children, corrective program for the elimination of negative psychic states and psychosomatic disorder in preschool children by means of body-oriented therapy and effectively a dynamic structural component for determining the changes and changes depending on corrective measures.

The formed principles of work of bodyoriented therapy with children. The program of body-oriented therapy, consisting of techniques and techniques of execution, the algorithm of work in specific block diagrams and its phased use, is presented. The program complexes under the "Relaxation" and "Activation" directions are considered. The instruments of influence on the touching body are given and their classification is given: earth, water, air, wood, metal, fire, as well as the techniques and techniques described therein. Described negative mental states to which this or that type of touch is applied. The aforementioned parts of the body through which one can influence the negative mental states of preschool children.
Key words: psychosomatics, negative psychic states, body-oriented therapy, preschoolers, body cartography, body contact.

\section{Ревуцкая Ирина Викторовна}

Стажер-исследователь кафедры управления, специальность «Психология», Государственного высшего учебного заведения «Университет менеджмента образования», Национальная академия педагогических наук Украины, Киев (Украина)

\section{КОНЦЕПТУАЛЬНАЯ МОДЕЛЬ КОРРЕКЦИИ НЕГАТИВНЫХ ПСИХИЧЕСКИХ СОСТОЯНИЙ И ПСИХОСОМАТИЧЕСКИХ РАССТРОЙСТВ У ДЕТЕЙ ДОШКОЛЬНОГО ВОЗРАСТА СРЕДСТВАМИ ТЕЛЕСНО- ОРИЕНТИРОВАННОЙ ТЕРАПИИ}

Аннотация. Статья посвящена негативным психическим состояниям и психосоматическим расстройствам детей дошкольного возраста и средствам их коррекции. Проанализированы некоторые публикации в отношении эмоциональных нарушений и факторов их возникновения у дошкольников.

В статье рассмотрена парадигма телесно-ориентированной терапии известных ученых мира, с учетом которой были разработаны коррекционные меры преодоления данной проблемы. Представлена концептуальная модель коррекции негативных психических состояний и психосоматических расстройств детей дошкольного возраста, ее структурные компоненты и психотехнология реализации.

Рассмотрены коррекционная программа и виды контактов преодоления негативных 
психических состояний и психосоматических

расстройств детей дошкольного возраста.

Рассмотрены программные комплексы по

направлению «Активизация» и

«Расслабление», а также техники и приемы их выполнения.

Ключевые слова: психосоматика, негативные психические состояния, телесноориентированная терапия, дошкольники, контакт, картография тела.

Дата отримання статті: 10.05 .2018

Дата рекомендації до друку: 17.05.2018

Дата оприлюднення: 24.05.2018

(C) Ревуцька I.B. 